Revista do CESP, Belo Horizonte, v.35, n.54, p. 135-137, 2015

\title{
JÚDICE, Nuno. Navegação de acaso. Lisboa: Dom Quixote, 2013. 93 p.
}

Edgard Reis

Universidade Federal de Minas Gerais

edgard.reis@uol.com.br

Recebido em 14 de junho de 2015

Aprovado em 16 de dezembro de 2015

Revelado há mais de quarenta anos, Nuno Júdice vem construindo uma obra poética extensa e multifacetada, que ultrapassa a marca de vinte e cinco títulos. Desde o início identificado como voz dissonante em relação à tendência formalista e fragmentária da década anterior, assume um registro discursivo, sem, contudo, abolir por inteiro a obsessão em debater a especificidade da poesia, intuito sugerido no título de estreia, $A$ noção de poema (1972). Outros autores surgem também à altura, como João Miguel Fernandes Jorge, com Sob sobre voz (1971) e Joaquim Manuel Magalhães, com Consequência do lugar (1974). O surgimento desses três autores motiva o conhecido comentário de Eduardo Prado Coelho: "São estes os acontecimentos decisivos para podermos assinalar uma linha de viragem na poesia portuguesa dos anos 70" (COELHO, $A$ noite do mundo. Lisboa: IN./C.M., 1988, p. 128). A enumeração poderia acolher outro poeta, de fluxo subjetivo, associações inesperadas e áspera sintaxe, António Franco Alexandre, de Sem palavras nem coisas, (1974).

No caso de Nuno Júdice, alguns vetores impõem-se para configurar a postura de um vidente, concepção de raiz romântica e rimbaudiana, na medida em que vê o poeta como portador de parte da sabedoria do universo, imerso numa rede de códigos fundamentais e referências literárias esotéricas. A sedução de um léxico fortemente contaminado pela prática romântica, retomado posteriormente pelos poetas simbolistas, sedimenta uma escrita caudatária de um desenvolvimento lírico matizado por uma nova perspectiva diante do sujeito, visto como instância do discurso. Construção de linguagem 
e espaço de reflexão teórica, a poesia retoma as convenções da tradição lírica, sem ignorar o tom artificial, a modulação erudita do repertório vocabular, o sentido ambíguo e a atmosfera fluida, nebulosa. Navegação de acaso, em que os poemas se mostram como "errantes navegações verbais" , último volume publicado pelo autor (2013), merecedor do galardão Prêmio Rainha Sofia de poesia ibero-americana, partilha desse entendimento prévio de que o universo poético instaura-se radicalmente num território circunscrito pela conotação, do qual a denotação se encontra de todo alijada: "Em vez de correr contra o tempo,/ separo de entre esses ramos de imagens aquelas que/ me ditaram os versos mais obscuros, a luz/ de acaso que deles surgia, em cintilações de sílaba,/ e um reflexo de madrugada na face liberta/ de uma lenta sombra", como se lê em "A manhã do poema". A vidência, na linha de Rimbaud, autor de decisiva influência em Júdice, (cf. "Alquimia" e "Cântico do fogo") supõe ainda o mergulho no inconsciente, a disponibilidade para acolher as imagens obscuras do sujeito, vedadas aos outros homens. Embora não seja a tônica do livro, esta faceta não está ausente, como se percebe em "Fecundação" e outros dois textos, em que as imagens beiram as sugestões de camadas psíquicas: "Derramo o esperma do sol sobre as éguas inseguras/ do ocidente; emprenho-as com a vaga humidade de um relinchar de abismo; (...)". A peculiaridade do discurso de Nuno Júdice subentende o fato de não mergulhar no próprio percurso, no itinerário pessoal. Frágil, tênue, por vezes tomada de um fôlego elevado, a voz lírica não se compraz na autocontemplação: a meta é compreender o encantamento em face do amor, da beleza, a extraordinária magia que cerca os gestos simples, as razões pelas quais as pessoas se emocionam, mas também as notas disfóricas diante de ruínas e mazelas sociais. A mistura de realidade e fantasia, a associação entre o plano real e o do sonho revela-se num tecido verbal de conformação estética, num sistema de trocas entre um sentido referencial e um outro assimilado, de natureza retórica: "E descubro-te no fundo desta imagem, envolta/ no veludo de ausência em que os meus dedos/ sentem a tua pele, e tiram de dentro do nada/ o calor das palavras com que o amor é esculpido/ na pedra do poema", (versos finais de "O amor"). Na tentativa de ouvir/decifrar o poema, em "Pedaço de real", o poeta refere o uso de recursos de linguagem ("o único recurso de que disponho são as próprias palavras"), como ferramentas capazes de criar o efeito diáfano e volátil do vivo arrebatamento, "algo que nasce/ de dentro do verso, e corre à minha frente".

Os lugares privilegiados nesta poesia, sabidamente as paragens estilizadas pela imaginação ou vidência, ancoram-se numa emblemática 
paisagem retórica, revisitada através da metáfora, da citação ou do labor artístico. A instância estética, de que dão sinais as associações à memória e a reiteração de alguns feixes semânticos (ligados à "tinta", "quadro", "cores", "pintor", "desenho", "luz", "palavra"), precede a realidade e assenta-se na concepção de arte como esforço artesanal e busca de perfeição: “(...) o poema, ou/ esse objecto artesanal que sai/ perfeito das mãos do oleiro, é/ afiado pela consciência de/ que só o que é exacto sobrevive/ no ouvido e canta" ("Proposta"). O cotidiano será sempre um pretexto para encetar um périplo nos códigos eruditos da arte e da cultura, limiar de um espaço autônomo propiciado pela tradição. No primeiro poema, "Cantar rústico", acompanhamos o interesse do sujeito em se purificar, para recepcionar a natureza: "Limpo de tédio os meus olhos para te receber,/ ó primavera, e um dilúvio de miosótis faz-me regressar/ à estação das chuvas, ouvindo o correr das águas/ numa impaciência de estuário", ao mesmo tempo em que registra o movimento em direção à inefável pastora, integrado numa atmosfera de leveza e artificialidade, na sequência de um ritual que se vai desenhando em detalhes, no qual o sujeito lírico a despe "da sua túnica de écloga, para que o seu corpo beba/ um licor de pétalas adormecidas". Ao longo do livro, alternam-se duas séries que se distinguem e se complementam: a série da epifania, com o encantamento diante da primavera, as visões femininas deslumbrantes e a possibilidade de compreender o mundo pela via artística. A série da devastação, de outro lado, mostra-se atravessada por "nevoeiros", "marés de sangue", "naufrágios", ruínas e miséria: "Mas era na terceira classe que eu encontrava/ os pobres que se sentavam sobre cestos carregados de legumes/ e de carnes secas" ("Infầncia"). No poema "Terra prometida", o lugar de fartura e felicidade não existe, a não ser "desertos", "pântanos e "campo de serpentes": para além do "nevoeiro", os inimigos só encontrarão "abutres", que "os esperam para limpar o que resta de carne/ nos seus corpos dizimados pela febre".

Ainda que sejam mínimos os vestígios escuros da realidade, as alucinadas imagens de devastação e ruína proliferam, "náufragos aproximam-se da costa, trazendo notícias/ do abismo com a voz entrecortada por um soluço/ de anémonas azuis". No poema "Regresso de Orfeu", o sujeito poético, ao constatar a sensação de exílio - "nenhuma/ paisagem me é familiar", insinua a definitiva impossibilidade de qualquer regresso, além do inexorável desaparecimento da amada, num mundo adverso e hostil ao seu ofício. 